Chirurgia (2019) 114: 747-752

No. 6, November - December

Copyright@ Celsius

http://dx.doi.org/10.21614/chirurgia.114.6.747

\title{
Endoscopic Gastroplasty. Initial Experience
}

\author{
Thierry Manos', Patrick Noel ${ }^{1,2,3}$, Christophe Bastid ${ }^{1}$, Ramon Vilallonga ${ }^{4,5,6}$, Marius Nedelcu ${ }^{1,6}$, Anamaria Nedelcu $^{6}$ \\ 'ELSAN, Clinique Bouchard, Marseille, France \\ ${ }^{2} \mathrm{ESH}$ Dubai Health Care City, Dubai, UAE \\ ${ }^{3}$ Mediclinic Airport Road, Abu Dhabi, UAE \\ ${ }^{4}$ Endocrine, metabolic and bariatric Unit, General Surgery Department, Hospital Vall d'Hebron, Barcelona, Spain \\ ${ }^{5}$ Universitat Autònoma de Barcelona, Barcelona, Spain \\ ${ }^{6}$ ELSAN, Clinique Saint Michel, Toulon, France
}

Corresponding author:

Marius Nedelcu, MD

Clinique Saint Michel

Centre Chirurgical de l'Obesite

Place du 4 Septembre, 83100

Toulon, France

E-mail: nedelcu.marius@gmail.com

Received: 3.11 .2019

Accepted: 2.12 .2019

\section{Rezumat}

\section{Gastroplastia endoscopică. Experiența initială}

Introducere: Procedurile bariatice endoscopice, în curs de dezvoltare, sunt mult mai puțin invazive ca opțiune de tratament pentru clasa I de obezitate. Scopul studiului nostru a fost de a evalua experiența inițială pe un an cu gastroplastia endoscopică (GE) din punct de vedere al rezultatelor ponderale, cât şi pentru evaluarea riscurilor acestei noi proceduri.

Metode: Acesta este un studiu prospectiv într-un singur centru pe 17 pacienți care au beneficiat de GE sub anestezie generală. Variabilele analizate au fost: modificarea greutății corporale şi complicațiile procedurii. Pentru a analiza corelațiile dintre IMC şi pentru a identifica factorii predictori pentru o mai bună pierdere în greutate după GE, pacienții au fost divizați în 2 grupuri: grupa A (cu IMC < 35 şi fără antecedente bariatrice - 10 pacienți) şi grupa B (cu IMC > 35, sau cu antecedente de balon gastric sau chirurgie bariatrică - 7 cazuri).

Rezultate: Un total de 17 pacienți au beneficiat de GE pentru obezitatea primară sau recidivă. Toți pacientii au fost de sex feminin, cu o vârstă medie de 38,7 ani. Media IMC a fost de $34,8 \mathrm{~kg}$ $/ \mathrm{m}^{2}$ (interval: 30,8 - 44,1). $\mathrm{Nu}$ au existat complicatii în timpul procedurii sau în perioada de după. Toți pacienții au fost externați în prima sau a doua zi după procedură, iar în viitor procedura va fi propusă în ambulatoriu. Patru pacienți (23,5\%) au prezentat durere postprocedurală moderată pe o perioadă medie de 7,75 zile (interval de 2-15 zile), iar alți doi pacienți au prezentat greață şi 
vărsături ameliorate de medicamentele intravenoase. Dintre cei 17 pacienți, pentru urmărirea postprocedurală au fost disponibili: 4 pacienți la 3 luni, 7 la 6 luni, 3 la 9 luni şi 3 au finalizat evaluarea pe 12 luni cu o pierdere în greutate medie de 46,1\%. Conform definiției ASGE, 70,6\% (n=12) din cei 17 pacienți au ajuns la $>25 \%$ din pierderea excesului ponderal. Toți pacienții din grupul A au înregistrat o pierdere în greutate cu succes şi pierderea medie de exces ponderal a fost $72,4 \%$, iar 5 din cei 7 pacienți din grupul B nu au reuşit să obțină un rezultat ponderal $>25 \%$. Mai mult decât atât, toți pacienții care au suferit o intervenție chirurgicală bariatrică anterioară nu au reuşit să obțină niciun rezultat în termenul de scădere în greutate în urma GE.

Concluzii: Gastroplastia endoscopică reprezintă o abordare minim invazivă sigură, care poate fi considerată o procedură eficientă şi bine tolerată, în special pentru tratamentul obezității primare pentru cei cu IMC < 35. Pentru pacienții cu proceduri chirurgicale anterioare bariatice sau cu obezitate severă, rezultatele sunt mai puțin favorabile.

Cuvinte cheie: plicatura endoscopică, gastroplastie endoscopică, clasa I, obezitate

\section{Abstract}

Introduction: Less invasive endoscopic bariatric procedures are under development for the management of class I of obesity. The purpose of our study is to evaluate endoscopic gastroplasty (EG) using a suturing method, as well as the perioperative care and outcomes, during one-year period.

Methods: This is a prospective single-center study over 17 patients using the EG under general anesthesia with overnight inpatient observation. The analyzed variables were: change in body weight; and adverse effects. In order to analyze correlations between BMI, and identify predictors for better weight loss after EG, we created 2 groups of patients: Group A (with BMI < 35 and primary obesity - 10 patients) and Group B (with BMI > 35, or previous gastric balloon or bariatric surgery -7 cases).

Results: A total of 17 patients underwent endoscopic procedures for primary obesity or weight regain. All patients were female with a mean age of 38.7 years. The mean BMI was $34.8 \mathrm{~kg} / \mathrm{m}^{2}$ (range: 30.8 -44.1). There were no major intra-procedure adverse events or during the follow up. All patients were discharged on the 1st or 2nd day following the procedure and in the future the procedure will be proposed in ambulatory setting. Four patients $(23.5 \%)$ were complaining of moderate postprocedural pain for a mean period of time of 7.75 days (range 2 - 15 days) and two other patients complained about nausea and vomiting alleviated by the intravenous drugs. Of the 17 initial patients, 4 were available for 3 -month of follow-up, 7 for 6 -month, 3 for 9 -month, and 3 completed the 12-month assessment with the mean EWL of $46.1 \%$. According to ASGE definition, $70.6 \%(\mathrm{n}=12)$ of the 17 patients reached $>25 \%$ of EWL. All patients in group A reached a successfully weight loss and the mean EWL was $72.4 \%$, but 5 out 7 patients in group B failed to achieve an EWL> $25 \%$. Moreover, all patients who underwent previous bariatric surgery failed to achieve any results in term of weight loss following EG.

Conclusions: Endoscopic gastroplasty represent a safe minimal invasive approach that can be considered as an effective and well tolerated procedure especially for primary obesity treatment. For patients with previous bariatric surgical procedures or with severe obesity the results are less favorable.

Key words: endoscopic plication, endoscopic gastroplasty, class I, obesity 


\section{Introduction}

According to the National Institute of Health (NIH), weight loss therapy is recommended for patients with a $\mathrm{BMI} \geq 35$ and for patients with a BMI between 30 and 35 or a high-risk waist circumference, and two or more risk factors. Bariatric surgery is recommended for well-informed and motivated patients with class III obesity (BMI $\geq 40$ ) or those with class II obesity (BMI $\geq 35)$ and significant obesityrelated comorbidities. It provides medically significant, sustained weight loss over a prolonged period of time, as well as significant improvement in comorbidities $(1,2)$. However, these surgical procedures carry a low rate of perioperative mortality and multiple longterm adverse events $(3,4)$.

In France, the national recommendations by HAS (Haute Autorite de Sante) are similar and bariatric surgery is not indicated for some obesity grades (BMI $<35$ or BMI 35-40 with no serious comorbidities). As a result, only a small percentage of the obese population may access bariatric surgery. For all the above, less invasive endoscopic procedures are under development

for the management of this category of obesity; they provide a higher number of yet untreated obese patients with no access to surgical weight loss therapies. The endoscopic bariatric procedures could be seen by some as the new menace in the bariatric field, while others see it as a new addition to the treatment arsenal for obesity (5). Kumar et al. summarized that endoscopic procedures are more effective than conservative measures, and more available and less invasive than bariatric surgery (6).

The purpose of this study was to evaluate our initial case series regarding the complications and short terms weight loss results of the EG.

\section{Methods}

A total of 17 patients were included in a prospective single-center study aand they received endoscopic gastroplasty (EG) between
January and December 2018 in Bouchard Private Hospital, ELSAN (Marseille, France). The selected inclusion criteria were the following:

- obese patients $\left(\mathrm{BMI}=30-40 \mathrm{~kg} / \mathrm{m}^{2}\right)$ who do not meet the criteria for surgery according to HAS. The patients are enrolled in a follow-up program to benefit from a multidisciplinary approach to morbid obesity disease for at least one year;

- patients $\left(\mathrm{BMI}>40 \mathrm{~kg} / \mathrm{m}^{2}\right)$ who refuse bariatric surgery for the risk of a potential complication;

- patients with a previous bariatric surgery who refuse an additional surgical procedure.

The following patients were contraindicated for EG: acute epigastric symptoms, potentially bleeding gastric mucosal lesions (ulcers, acute gastritis), neoplastic lesions, hiatus hernia $>3 \mathrm{~cm}$, coagulopathy, and psychiatric disorders. All patients underwent standard evaluation with upper endoscopy, nutritional and psychological counseling and multidisciplinary team evaluation for 2 months prior to EG.

The American Society for Gastrointestinal Endoscopy (ASGE) and the American Society for Metabolic and Bariatric Surgery (ASMBS) taskforce definedthe threshold of $25 \% \% \mathrm{EWL}$ at one year to measure the efficacy of endoscopic therapies for weight loss (7). All patients had a double dose of Proton Pump Inhibitors (PPIs) until the healing process was achieved. The procedure of EG and the current study obtained the IRB approval. Informed consent was obtained from all individual participants included in the study.

\section{Technique Description}

The EG is classified as a restrictive procedure with the main purpose, to diminish the gastric capacity. This is achieved by several complete endoscopic transmural sutures aiming to realize a line of cinched plications at the level of the greater curvature. The result is similar to a sleeve gastrectomy only on the inferior part of the gastric body, (Fig. 1) with no modification of the gastric fundus. The mechanism of action 

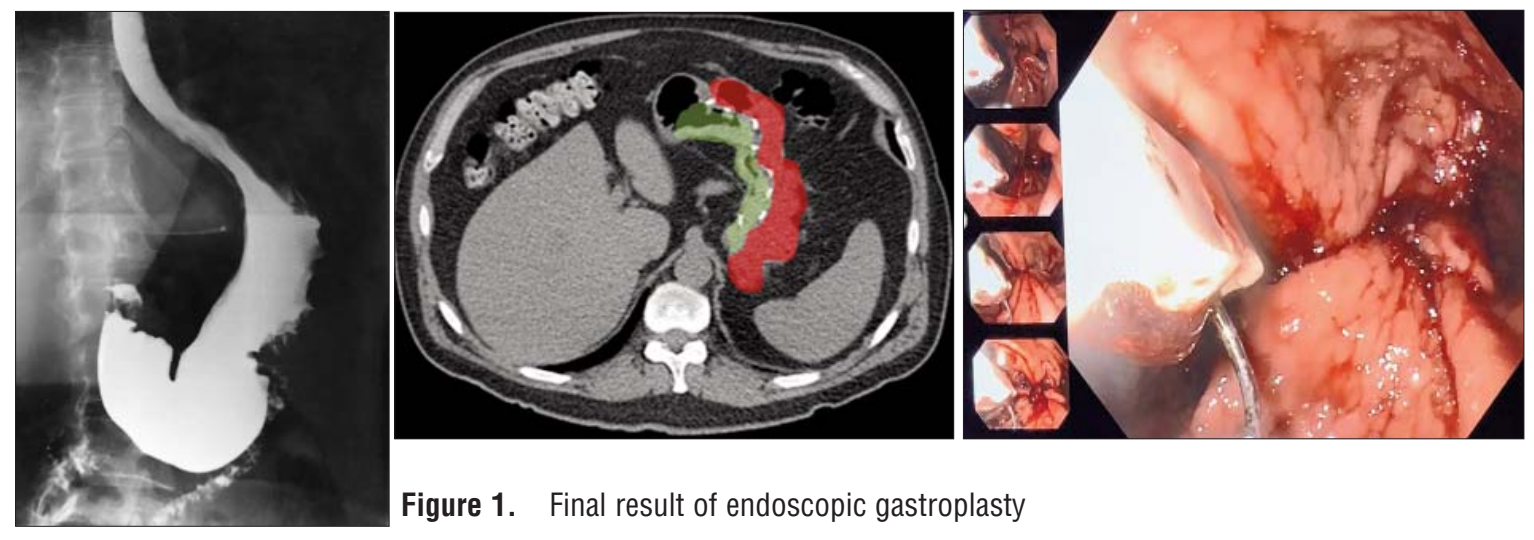

Figure 1. Final result of endoscopic gastroplasty

and the gastric emptying time is completely different compared to sleeve gastrectomy. The endoscopic suturing device (OverStitch; Apollo Endosurgery Inc., Austin, Texas, USA) is used with a dual channel endoscope (GIF-2T160; Olympus Medical Systems Corp., Tokyo, Japan) to perform the EG. The general anesthesia with endotracheal intubation is always required and the patient is placed in dorsal decubitusor in a left lateral position. To assure the safety of the procedure and to facilitate the maneuvers, a specifically designed esophageal overtube (Apollo Endosurgery, Austin, TX, USA) should be used. At the end of the procedure, a control gastroscopy is mandatory in order to asses the final aspect of the gastroplasty and to check any potential bleeding.

After the procedure, the patient is under clinical surveillance for the first 24 hours. The liquid tolerance/intake is started after 8 hours and complete blood check up is realized the day following the procedure to rule out any complication. Upper gastrointestinal swallow is performed at different timepoints after the procedure to assess the gastroplasty.

\section{Statistical Analysis}

Continuous demographic variables were expressed as mean \pm standard deviation, and range; categorical variables as well as complications were reported as number and percentage. Continuous outcome variables were generally reported as mean \pm standard deviation, and range. Descriptive statistics (simple counts and mean values) were used to report the complications and adverse effects.

\section{Results}

A total of 17 patients underwent endoscopic procedures for primary obesity or weight regain. All patients were female with a mean age of 38.7 years. The mean BMI was 34.8 (range: 30.8 - 44.1).

There were no major intra-procedure adverse events or during the follow up. All patients were discharged on the $1^{\text {st }}$ or $2^{\text {nd }}$ day following the procedure and in the future the procedure will be proposed in ambulatory setting.

Four patients $(23.5 \%)$ were complaining of moderate postprocedural pain for a mean period of time of 7.75 days (range 2-15 days) and two other patients complained about nausea and vomiting alleviated by the intravenous drugs.

Of the 17 initial patients, 4 were available for 3-month of follow-up, 7 for 6 -month, 3 for 9-month, and 3 completed the 12-month assessment with the mean EWL of $46.1 \%$. In order to analyze the correlation between the initial BMI and the EWL following EG, we created 2 groups of patients: Group A (with BMI $<35$ and primary obesity -10 patients) and Group B (with BMI > 35, or previous gastric balloon or bariatric surgery -7 cases).

According to ASGE definition, $70.6 \%(\mathrm{n}=$ 12) of the 17 patients reached $>25 \%$ of EWL. All patients in group A reached a successfully 
weight loss and the mean EWL was $72.4 \%$, but 5 out 7 patients in group B failed to achieve an EWL> $25 \%$. Moreover, all three patients who underwent previous bariatric surgery (one patient with a previous sleeve gastrectomy and two patients with gastric bypass) failed to achieve any results in term of weight loss.

\section{Discussion}

Obesity is considered nowadays a chronic disease that became an epidemic with important economical implication. The majority of patients struggled for many years with noninvasive measures like diet and exercise and pharmacotherapy. Regarding bariatric surgery, many patients either do not qualify or are unwilling to undergo surgical procedure. Endoscopic gastroplasty can fill this treatment gap, helping them to change lifestyle habits necessary to perpetuate long-term success. A multidisciplinary team of bariatric professionals is essential to provide patients with ongoing education and support.

The EG was incriminated that is not durable. However, we all know that all bariatric procedures have an important effect during the first 12 to 18 months. Initial report of EG showed similar efficiency and durability (8-10). Moreover, it should also be mentioned that EG present another important advantages. No irreversible anatomical alteration occurs in the gastric cavity, all the EG are reproducible and repeatable; thus might allow for reintervention in the future to achieve lasting results. Even if our current study showed that no major adverse effect was recorded, the reversibility of EG could be adopted if needed in case of an eventual major complication.

Our study demonstrates that EG represents a safe minimal invasive approach that can be considered as an effective and well tolerated procedure especially for primary obesity treatment.

Revisional bariatric surgery has been considerate to be less effective than the primary procedure and associated with higher risk profile for complication (11). Similarly, EG presents less encouraging results for revisional cases following bariatric procedure even if the risk of complications is similar. In our experience, 3 patients underwent previous bariatric procedures (two cases of Roux en Y gastric bypass and one case of sleeve gastrectomy) with negative results in term of EWL following additional bariatric endoscopic procedures.

Initially, EG was very often compared with sleeve gastrectomy. Despite the fact that no part of the stomach is removed the final form of the gastroplasty is completely different with the form of the sleeve gastroplasty. Moreover, the mechanism of action of EG is different from the sleeve gastrectomy. Contrary to a rapid gastric emptying for sleeve, the EG delays gastric emptying as it was showed by et Abu Dayyeh et al (12).

Even if Espinet-Coll et al (13) described the risk of suture passing close to the hilum of the spleen with the risk of catastrophic hemorrhage and the need for splenectomy in our experience no major adverse events occurred during the procedure. In another study, Lopez-Nava et al (14) assessed 248 patients treated with EG using the Apollo OverStitch system (2017). Severe adverse events occurred in $2 \%$ of cases (5 patients) but none of them required surgical intervention. Perigastric fluid collections were observed in 2 patients. One patient suffered a haemorrhage into the abdominal cavity, which was managed conservatively. In one patient, pulmonary embolism occurred post-operatively, and one patient developed pneumothorax and pneumoperitoneum that required drainage.

In the same study, the most common minor complications were abdominal pain and nausea with incidence ranging from 27.47 to $80 \%$ and 38.46 to $80 \%$, respectively. In our series the pain was recorded in a similar percentage of $23.5 \%$.

Our study has several limitations to consider. First, our data represents one year experience of a single institution which limits generalizability. Furthermore, our sample size is relatively small and may reduce our ability 
to uncover differences when they may in fact exist. However, we were able to abstract a robust conclusion, a group of patient (BMI over 40 or previous bariatric surgery) with not encouraging results. The strength of EG and consequently to our study is represented by the very low number of complications.

\section{Conclusion}

Endoscopic gastroplasty represents a safe minimal invasive approach that can be considered as an effective and well tolerated procedure especially for primary obesity treatment. For patients with previous bariatric surgical procedures or with severe obesity the results are less favorable.

\section{References}

1. Karlsson J, Taft C, Ryden A, Sjöström L, Sullivan M. Ten-year trends in health-related quality of life after surgical and conventional treatment for severe obesity: the SOS intervention study. Int J Obes. 2007;31(8):1248-61.

2. Mingrone G, Panunzi S, De Gaetano A, Guidone C, laconelli A, Leccesi $L$, et al. Bariatric surgery versus conventional medical therapy for type 2 diabetes. N Engl J Med. 2012;366(17):1577-85

3. Chang SH, Stoll CR, Song J, Esteban Varela J, Eagon CJ, Colditz GA. The effectiveness and risks of bariatric surgery: an updated systematic review and meta-analysis, 2003-2012. JAMA Surg.
2014;149(3):275-87.

4. Griffith PS, Birch DW, Sharma AM, S Karmali. Managing complications associated with laparoscopic Roux-en-Y gastric bypass for morbid obesity. Can J Surg. 2012;55(5):329-36.

5. Sullivan S, Edmundowicz SA, Thompson CC. Endoscopic bariatric and metabolic therapies: new and emerging technologies. Gastroenterology. 2017;152(7):1791-801.

6. Kumar N. Weight loss endoscopy: development, applications, and current status. World J Gastroenterol. 2016;22(31):7069-79

7. ASGE/ASMBS Task Force on Endoscopic Bariatric Therapy, Ginsberg GG, Chand B, Cote GA, Dallal RM, Edmundowicz SA, Nguyen NT, et al. A pathway to endoscopic bariatric therapies. Surg Obes Relat Dis. 2011;7(6);672-82.

8. Storm AC, Abu Dayyeh BK. Endoscopic sleeve gastroplasty for obesity: defining the risk and reward after more than 1600 procedures. Gastrointest Endosc. 2019;89(6):1139-1140.

9. Lopez-Nava G, Galvăo MP, Bautista-Castaño I, Fernandez-Corbelle JP, Trell M, Lopez N. Endoscopic sleeve gastroplasty for obesity treatment: two years of experience. Arq Bras Cir Dig. 2017;30(1): 18-20. English, Portuguese

10. Jain D, Bhandari BS, Arora A, Singhal S. Endoscopic sleeve gastroplasty - A New Tool to Manage Obesity. Clin Endosc. 2017; 50 (6): 552-561.

11. Spyropoulos C, Kehagias I, Panagiotopoulos S, Mead, Fotis Kalfarentzos. Revisional bariatric surgery 13-year experience from a tertiary institution. Arch Surg 2010;145(2):173-7.

12. Vargas J, Storm A, Bazerbachi F, Abu Dayyeh B. Accelerated gastric emptying is associated with improved aspiration efficiency in obesity. BMJ Open Gastroenterol. 2019;6(1):e000273. Published online 2019 Apr 10.

13. Espinet-Coll E, Nebreda-Durán J, López-Nava-Breviere G, Ducóns García, Rodríguez-Téllez M, Crespo García J, et al. Multicenter study on the safety of bariatric endoscopy. Rev Esp Enferm Dig 2017;109(5):350-7

14. Lopez-Nava G, Sharaiha RZ, Vargas EJ, Bazerbachi F, Manoel GN, Bautista Castaño I, et al. Endoscopic sleeve gastroplasty for obesity: a multicenter study of 248 patients with 24 months follow-up. Obes Surg. 2017;27(10):2649-2655. 